\title{
THE EFFECTIVENESS OF A HEALTH PROMOTION MODEL ON THE FATHER'S SELF EFFICACY IN STIMULATING THE GROWTH AND DEVELOPMENT OF TODDLER
}

\author{
Ririn Probowati \\ STIKES Pemkab Jombang \\ Jombang, Indonesia \\ ririn_probowati@yahoo.com \\ Monika Sawitri Prihatini \\ STIKES Pemkab Jombang \\ Jombang a, Indonesia
}

\author{
Heri Wibowo \\ STIKES Pemkab Jombang \\ Jombang, Indonesia \\ Praba Diyan Rachmawati \\ Faculty of Nursing, Universitas Airlangga \\ Surabaya, Indonesia
}

\begin{abstract}
Introduction:the growth and development of toddler is not only influenced the mother, but also the father. Lack of belief in the father's ability in providing stimulation of growth and development will have an impact on the achievement of the optimal toddlers' growth and development. The purpose of this study was to develop a model of health promotion in improving father's selfefficacy to stimulate the growth and development of toddlers in father's POSYANDU. Methods: this study used explanative observational cross sectional research design. The population was a father who has a toddler in father's POSYANDU of Losari village, PlosoJombang in 2016, 55 respondents were participated in this study. forty two samples were recruited with simple random sampling techniques. The variable in this study is a benefit factor. Resistance factor, the factor of the capabilities themselves, influence factors caused due to stimulation, factors influenced the interpersonal, situational factor influencedthe stimulation the growth and development of infants, factor of father's self efficacy, commitment of father, the behavior of the father, the growth and development of infants using questionnaires and observation sheets. Data analysis techniques used PLS. Result: all ffactor influenced the stimulation of the toddlers' growth and development by father. All of the variables are significant with $t$ score $=>1.96$. The model of health promotion in enhancing father's self efficacy which influenced by all variables.Conclusion:the enhancement of father's self efficacy in giving the stimulation of growth and development could be a verbal persuasion, which could influenced father, finally it wished to use as basic way in health promotion which was concluded into a module in order to be given after followed father's POSYANDU in the counseling desk.
\end{abstract}

Keywords - Father's self efficacy, stimulation, toddler

\section{INTRODUCTION}

Parents (father and mother) play an important role to ensure sustainable growth of toddler. In order to achieve the growth and development optimally, the infant and toddler need to be provided with the basic needs such as physical/ biomedicine, emotion/ affection and stimulation needed/ education. One of the parents' roles is to nurture the infant and stimulate the growth and development in pre-birth phase and golden age phase (newborn -5 years), the first five years of child is very crucial to ensure they achieve optimal growth and development[1].

In recent rapid development of Indonesia many mothers has begin to enter in to labour force. mothers has to assume the role of housewife at the same time participated as active labour outside the house to support the financial as a result the child would be left at home while the mother is at work. Hence the responsibility of the bring up the infant and toddlers is shared between father and mother. toddler needs stimulation from parents (mother and father) in order to growth and develop optimally. Especially in first 1000 days which is the important period for growth and development of a baby where giving stimulation and good nutrition will eusure they reach the optimal cognitive development[2].

Various efforts to optimize the toddler's growth and development have been initiated by the government and social network by role enhancement among mother, father and family in order to establish self efficacy or the beliefs in the ability to stimulate the growth and development of toddler. The activity 
of POSYANDU (Integrated health post) consists of POSYANDU, the founding of toddler's family and PAUD as an activity which is held by the social and for social in order to have a social which able independently doing the stimulation of growth and development, so thath the toddler can grow and develop optimally [2].

POSYANDU which is usually conducted by the woman and picked the toddler up by the mother, grandmother, aunty who all of them are women. A child in his/her growth and development also need stimulation from father. The effort of father's growth and development stimulation could be reached by POSYANDU of father. The expectations of father who crave a close relationship with his children start from neonates and then actively participate in his children's life. But how can the father do it if the social promotes traditional gender's role in which woman as a main educator and man as a source of incomes, therefore he may not be able to play an active role in his children's life if he must work all day and this activity in ordinary day, it needs to involve father's role or man in POSYANDU or we called father's POSYANDU.

As a means of evaluation of father's self efficacyin giving stimulation in growth and development of toddler can be conducted through the theory of health promotion model by Nola J.Pender(Terry Kyle \& Susan Carman, 2016). The concept of the model of health promotion is the optimal health in which we can see from the optimal growth and development of the toddler. One of the influenced in growth and development of toddler is the father's stimulation. He can give a good stimulation if he has knowledge about stimulation which held in father's POSYANDU.

This Theory supports the importance of cognitive process which is called social cognitive theory included self confidence in changing attitude. Social cognitive theory included self confidence (self efficacy) which influenced from cognitive and affective aspect from the unique attitude [3].

The theory concept of Barbara Resnick (Bandura 1997): self Efficacy is based on the person's behavior to the something is thought, believed, and will influence someone's feeling to do the action. Self Efficacy process is a cognitive process which begin with someone's action based on his his thought to do something. Motivation processes is a process that encouraged one self and the action is directed by previous thought. Affective process is a process that set the emotional condition process and reactions. Selection process require individual's ability to review and specified a situationsof activities(Bandura, 1977). increased self-efficacy among fathers will indirectly increase their confidence and ability to stimulate growth and development of toddler. One way to increase self-efficacy is verbal persuasion: verbal persuasion iswidely used to convince someone that they have the ability to achieve the objectives of education directly.

The result of previous study which was conducted in November 2016 among father's POSYANDU of Losarivillage PlosoJombang district from 22 toddlers, 10 of them were experienced a rise in body weight, while 6 toddlers' weight were dropped and 18 toddlers progressed based on their age and 4 toddlers have not achieved development. The role of father in POSYANDU was still lacking as perceived by mother.

Based on the explanation above, the researcher was interested to develop the models of health promotion in improving self-efficacyof father to stimulate the growth and development of young children in the father's posyandu of Losari village Ploso Jombang

\section{METHODS}

The design of this research study was an observational cross sectional in order to create a model for health promotion in improving father'sself-efficacy in stimulate the growth and development of toddlers. This study examined the factors of cognition aspects and affection of father's self efficacy which influenced the growth and development of toddlers which consists of benefit factor, resistance factor, the assurance factor of the ability or self-efficacy, influence factors factors of interpersonal influence, the influence of situational factors stimulated growth and early childhood development, identify the growth and development of them. The end of this phase was to create a model for health promotion in improving father'sself-efficacyin stimulating growth and development of toddlers using the model of health promotion in father'sPOSYANDU of Losari village PlosoJombang. The populations in this study were all fathers $(\mathrm{N}=55)$ who have a toddler in father's POSYANDU simple random sampling technique was used to recruit 42 fathers.

The instruments used in this study were questionnaires, observation sheets with a guide Pre-Screening Questionnaire Development (KPSP), Table weight / height for the early detection of irregularities growth. Analysis of the data in this study used SEM PLS. Based on the results of data processing, further analysis of the results of SEM to evaluate the PLS structural equation model (Ghozali 2005).

\section{RESULTS}

TABLE I. AFFECTIVE AND COGNITIVE FACTORS OF FATHER STIMULATE THE GROWTH AND DEVELOPMENT

\begin{tabular}{|c|c|c|c|c|}
\hline \multirow[t]{2}{*}{ No } & \multirow[t]{2}{*}{ Characteristic } & \multirow[t]{2}{*}{ Category } & \multicolumn{2}{|c|}{ Frequency } \\
\hline & & & $\sum$ & $\%$ \\
\hline \multirow[t]{3}{*}{1} & \multirow[t]{3}{*}{ The benefit perception } & Good & 4 & 10 \\
\hline & & moderate & 36 & 85 \\
\hline & & Less & 2 & 5 \\
\hline \multirow[t]{3}{*}{2} & \multirow{3}{*}{$\begin{array}{l}\text { The } \\
\text { perception }\end{array}$} & Good & 8 & 19 \\
\hline & & moderate & 30 & 71 \\
\hline & & Less & 4 & 10 \\
\hline 3 & confidence & Good & 5 & 12 \\
\hline
\end{tabular}




\begin{tabular}{|c|c|c|c|c|}
\hline & \multirow[t]{2}{*}{ perception } & moderate & 30 & 71 \\
\hline & & Less & 7 & 17 \\
\hline \multirow[t]{3}{*}{4} & \multirow[t]{3}{*}{ The shown effect } & Good & 12 & 28 \\
\hline & & moderate & 28 & 67 \\
\hline & & Less & 2 & 5 \\
\hline \multirow[t]{3}{*}{5} & \multirow[t]{3}{*}{ Interpersonal influence } & Good & 16 & 38 \\
\hline & & moderate & 24 & 57 \\
\hline & & Less & 2 & 5 \\
\hline \multirow[t]{3}{*}{6} & \multirow[t]{3}{*}{ Situational influences } & Good & 14 & 34 \\
\hline & & moderate & 26 & 61 \\
\hline & & Less & 2 & 5 \\
\hline \multirow[t]{3}{*}{7} & \multirow[t]{3}{*}{ commitment to plan } & Good & 24 & 57 \\
\hline & & moderate & 18 & 43 \\
\hline & & Less & - & \\
\hline \multirow[t]{3}{*}{8} & \multirow[t]{3}{*}{ Self efficacy } & Good & 12 & 29 \\
\hline & & moderate & 26 & 61 \\
\hline & & Less & 4 & 10 \\
\hline \multirow[t]{3}{*}{9} & \multirow[t]{3}{*}{ Behavior } & Good & 7 & 17 \\
\hline & & moderate & 28 & 67 \\
\hline & & Less & 7 & 16 \\
\hline \multirow[t]{4}{*}{10} & \multirow[t]{4}{*}{ Growth } & Fatty & 4 & 10 \\
\hline & & Normal & 33 & 79 \\
\hline & & Tiny & 4 & 10 \\
\hline & & Very Tiny & 1 & 1 \\
\hline \multirow[t]{3}{*}{11} & \multirow[t]{3}{*}{ Development } & Suitable & 35 & 83 \\
\hline & & Misdoubt & 5 & 12 \\
\hline & & Deviation & 2 & 5 \\
\hline
\end{tabular}

TABLE II. THE RESULT OF COEFFICIENT EXAMINING IN STIMULATION'S MODEL

\begin{tabular}{|c|c|c|c|}
\hline Influenced & $\begin{array}{c}\text { Coef } \\
\text { Original }\end{array}$ & $\begin{array}{c}T \\
\text { table } \\
\end{array}$ & $T$ test \\
\hline $\begin{array}{lr}\begin{array}{l}\text { Personal } \\
\text { (X1) }\end{array} & \text { Factor } \\
\text { Commitment }(\mathrm{X} 4)\end{array}$ & 0.220 & 1.96 & 3.417 \\
\hline $\begin{array}{l}\text { Behavior } \\
\text { Factor(X2( } \\
\text { Commitment (X4) }\end{array}$ & 0.427 & 1.96 & 3.504 \\
\hline $\begin{array}{l}\text { Self efficacy (X3)--- } \\
\text { (X4) Commitment }\end{array}$ & 0.257 & 1.96 & 2.250 \\
\hline \begin{tabular}{l}
\multicolumn{2}{l}{ Commitment(X4) -- } \\
- (X5) $^{2}$ Behavior \\
\end{tabular} & 0,236 & 1.96 & 3.078 \\
\hline $\begin{array}{l}\text { Behavior (X5) } \\
----- \\
\text { growth (Y1) }\end{array}$ & 0,426 & 1.96 & 5.073 \\
\hline \begin{tabular}{ll}
\multicolumn{3}{l}{ Behavior (X5)------- } \\
\hdashline- & development \\
(Y2) &
\end{tabular} & 0.321 & 1.96 & 4.345 \\
\hline
\end{tabular}

For the Aspect of cognition and or enoughaffection of father in providing stimulation of growth and development, $85 \%$ of them had perceived benefits factors moderately A perceived barrier to stimulate is less than $10 \%$. Father'sSelf efficacy in stimulate the growth and development of fraction $29 \%$. Father'sBehavior is less by $16 \%$ in providing stimulation. Father's commitment to plan behavior almost a half enough stimulation as many as $43 \%$. Growth of toddlers still experienced thin of body weight as many as $11 \%$ and development of toddlers fraction of them did not appropriate as $17 \%$.

The measurement results of Outer Variable Weight Indicators research shown that all loading factor> 0.5 and composite realiability $>0.6$ which indicates that the instrument used to declare the valid and reliable to measure the commitment of fathers in providing stimulation of growth and development of toddlers.

The results of this research data processing used SmartPLS with R-square value as shown in Table 2 shown that all of the $\mathrm{R}$-square value is greater than zero, it means that our model had achieved Goodness of fit

Table 2 shows that the results of personal factor impact positively and significant on commitment factor. Personal factors directly affected the commitment as many as 0.220 , which means that every increase in the personal factor will increase the commitment also as many as 0.220.Behavior factor affect also had significant positive correlation with commitment factor. Behavioral factors directly affect the commitment by 0.427 , which means that every increase in the behavioral factorswill increase the commitment factor also as many as 0.427 . Self efficacy'sFactors influenced positive and significant effect on the commitment factor. Self efficacy factors directly affect the commitment by 0.257 , which means that every increase in self-efficacy factor will increase commitment also for 0257. Commitment affect positive and significant effect on behavior. Commitment directly affect the behavior of 0.236, which means every increase in the commitments will increase behavioralso for 0.236 .

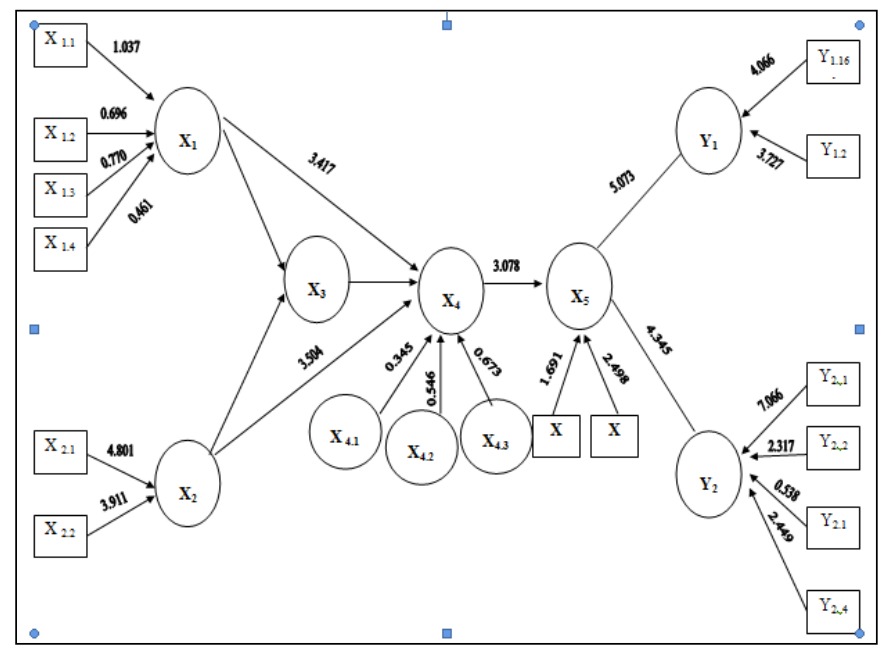

Fig. 1. Model's structure 
Behavior had significant positive effect on growth. Behavior directly affected the growth of 0.427 , which means that every increase in behavior that would raise the growth factor of 0.427. Behavior had significant positive impact on the development. Behavior directly affected the development by 0.321 , which means that every increase in behavior that would raise the growth factor of 0.321 . This research used Focus Group Discussion (FGD) to obtained more in-depth understanding of father's self-efficacy in giving the growth and development stimulation to toddler in father's POSYANDU Losari village PlosoJombang.

Results from FGD shows the lack of knowledge about father's role to stimulate the growth and development of toddlers, the assurance Lack of knowledge about the

Perception of fathers in providing stimulation and growth, less precise in providing stimulation of the improvement father's development, the assurance Lack of fathers in determining the commitments in the stimulation of growth and development of toddlers.

FGD findings revealed the needsfor training to improve father's self efficacy in stimulating the growth and development of toddlers, Need for guidance in improving father'sself-efficacy in stimulating the growth and development of toddlers in the form of guidelines (modules) for father in providing stimulation which includes sense of stimulation, stimulation way, the principle of stimulation, the tools used to provide stimulation, timing of stimulation, the terms of children can be given by stimulation.

\section{DISCUSSION}

More than $70 \%$ factor of perceived benefits to stimulate growth and development, perceived obstacles to the stimulation of growth and development, perceptions of themselves with the enough assurance. It happens the possibilities of these factors were influenced by the experience of father in providing stimulation of growth (Notoatmojo, 2007).

Father's commitment in providing stimulation of growth and development was moderate, $\mathrm{f}$ that affected the commitment was the father's level of knowledge in providing stimulation of growth and development.

The analysis results of the relationship between variables of father's behavior in the stimulation of growth and development of toddlers had established a models( table 4.5) all grades RSquare showed > zero $(0)$ means that this research model achived the required Goodness of Fit. A model was good if the value of Goodness of Fit> 0:09 and the maximum value $=1$ (one) [6].

The behavior to plan an action was influenced by 1) the previous behavior associated consisting of perceived benefits of an action, perceived barriers against inaction, perceptions of the assurance, the effect caused by an activity. 2) the personal factor consisting of families, groups, health providers, norms, support models. Situational influences: the available options, characteristics and needs, aesthetics that would affect a person's health promotion. [3].

The stimulating growth and development among would increase father's selg efficacy is good beside their positive behavior of father in iniating stimulation in growth anf development. Commitment was a determination or motivations that predispose a person to perform an action. A person who has Less commitment often would have negative behavior and not committed to perform any action.. If a father has less committed he would has less preferably behavior in providing stimulation of growth and development that will ultimately affect the growth and development of toddlers. In the model of health promotion, a person would perform health promotion when he/she is committed. In this study, before he had a commitment to plan stimulation of growth and development of the father should have good self efficacy. He must have assurance in his capabilities to provide stimulation to the growth and development of toddlers. He was the closest person after the mother because the father was also share responsibility for the growth and development of them. A father also wanted to be involved in the growth and development of babies and he would be proud if having a child grow and develop optimally. In order for father to have assurance ability (self-efficacy) in the stimulation of the growth of the father required knowledge in providing stimulation.

One way to improve self efficacy is through verbal persuasion which is widely used to persuade someone who had the ability to achieve the goals they seek. People who received verbal persuasion often potray the ability to accomplish the tasks given and will exert a greater effort than people who were not persuaded (Bandura 1977). father's self efficacy in providing father'sstimulation could be improved with the provision of information referring to a book / modules that can be done in a credible form of father'sPOSYANDU. Counseling could be done by a health providers if they are trained and equipped with operating manual.

\section{CONCLUSION}

To give the verbal persuasion with guideline that could be given in the form of currently modules in Father's POSYANDU activities.

The educational institutions should consider develop courses for community children and approach of the health promotion concept of behavior through health education used a guidebook / module.

For health providers made simplify and homogenize health promotion with a module in providing stimulation of growth and development of toddlers, for the respondent was to facilitate and stimulate father to come to father's POSYANDU since there was promoting of health education in the form of stimulation of growth and development of toddlers using a structured module. 


\section{REFERENCES}

[1] Soetjiningsih, Tumbuh Kembang Anak. Jakarta: EGC, 2007.

[2] T. Kyle and S. Carman, Buku Ajar Keperawatan Pediatri. Jakarta: EGC, 2016.

[3] N. . Pender, C. . Murdaugh, and M. A. Parson, Health Promotion in Nursing Practice (6th ed). New Jersey: Upper Saddle River, 2002.
[4] A. Bandura, "Self-efficacy: Toward a unifying theory of behavioral change," Psychol. Rev., vol. 84, pp. 191-215, 1977.

[5] S. Notoatmojo, Ilmu Kesehatan Masyarakat. Jakarta: PT. Rineka Cipta, 2007.

[6] I. Ghozali, Aplikasi Analisis multivariat dengan program SPPS edisi 3. Semarang: Penerbit UNDIP, 2005. 